UDC

DOI: $10.17223 / 18572685 / 51 / 17$

\title{
CONVENTIONALITY AS A FACTOR FOR THE SUSTAINABLE DEVELOPMENT OF THE SOCIETY
}

\author{
E.M. Bobkova \\ Taras Shevchenko State University of Transnistria \\ 107 October 25 Street, Tiraspol, 3300, Transnistria, Moldova \\ E-mail: icnew-age@yandex.ru
}

\section{Abstract}

The article discusses the social and conventional mechanisms of the society sustainable development. The author concludes that sustainable development of the society in the considered region is based on the organic solidarity and trust in the conditions of a frozen conflict. She also explains the ratio and mutual influence of subjective factors and objective conditions of the social convention and analyses the main principles of interrelation of conventionality and sustainable development of social systems. According to the author, strengthening the stability of society requires improved democratic mechanism of consolidated public interests and favorable conditions for the development of conventionality.

The author introduces a methodology for measuring conventionality, which includes three areas of measurement: economic, political and social. Some examples from the study of trade interactions in the border are provided to illustrate the developed model. The methodology and the results of the research indicate the ability to control the sustainability of development in this area.

Keywords: conventionality, solidarity, social-conventional mechanism, sustainability, integrity. 


\section{КОНВЕНЦИОНАЛЬНОСТЬ КАК ФАКТОР УСТОЙЧИВОГО РАЗВИТИЯ ОБЩЕСТВА}

\section{Е.М. Бобкова}

Приднестровский государственный университет им. Т.Г. Шевченко Молдова, Приднестровье, 3300, г. Тирасполь, ул. 25 октября, 107

E-mail: icnew-age@yandex.ru

\section{Авторское резюме}

Рассматривается социально-конвенциональный механизм устойчивости общества. Осмысливаются соотношение и взаимовлияние субъективных факторов и объективных условий социальной конвенции. Анализируются основные принципы взаимосвязи конвенциональности и устойчивого развития социальных систем. Делается вывод, что условием укрепления устойчивости общества выступают совершенствование демократического механизма консолидации общественных интересов, создание благоприятных условий для развития конвенциональности. Особое внимание уделяется механизму социальной конвенции, который в условиях конфликта позволяет создавать конвенциональную платформу для урегулирования интересов противоборствующих сторон. Молдавско-приднестровский конфликт до настоящего времени не получил системной конвенциальной оценки устойчивости, уровня доверия между сторонами и оценки эффективности применяемых мер по его формированию на экспертном уровне. Вводится в оборот методология измерения конвенциональности, включающая в себя три области измерения: экономическую, политическую и социальную. Для иллюстрации применения разработанной модели на практике приведены некоторые примеры из исследования торговых взаимодействий в сфере пограничья. Методика и полученные результаты исследования свидетельствуют 0 возможности контролировать устойчивость развития в данной сфере, принимать эффективные управленческие решения и формулировать первоочередные действия, позволяющие нормализовать торговлю между Молдовой и Приднестровьем.

Ключевые слова: конвенциональность, солидарность, социально-конвенциональный механизм, устойчивость, целостность.

The first quarter of the $21^{\text {st }}$ century was marked by a radical growth of the actuality of the sustainable development of the humanity, taking a priority place in the sociological studies. The transformational processes, which are characteristic today for all the domains of knowledge, provide the scientists with new instruments for scientific cognition. Today we 
may observe the growing concern of the experts, governments and the community about the worsening of the situation on the planet: global economic and financial crises, local political conflicts (including the military ones), the rise of terrorism, technological and environmental disasters (Aitimov et al. 2016). The contemporary global strategy for a sustainability requires innovation-based approaches, taking into account each society's life standards characteristics and regional peculiarities. In case we view the region as a "a human-sized self-developing system", for which the most characteristic is its openness, then we should consider the danger of losing the "subjectivity" in the current circumstances of the global development. (Lektorskij 2010: 5-18).

Accordingly, the region may be presented as a system, with certain mechanisms created, which accumulate the experience and peculiarities of the interaction with the environment meaningful for its integrity and sustainability. The functioning of the mentioned system offers a complicated developing complex: the individual - the economic system - the political system - the political system - the ecological system - the cultural and linguistic mediums etc. (Stepin 2003: 5-17) The understanding of this system is based on the knowledge of the learning and acting subjects, interpreted in accordance with their subjective realities.

In our case the system is characterized by a self-organization, openness and non-linearity (Leksin, Shvecon 2012). In the conditions of a synergy we may notice the interweaving of linearity and non-linearity, sustainability and unsustainability, continuity and discreteness, stability and structural changes, defining the self-development the system by extending and deepening the feedback (Zang 1999). One of the issues of the sustainability from the point of view of sociology is the fundamental importance given to the comprehension of the correlation and mutual influence of the subjective factors and objective conditions.

Therefore, the real sustainability of the society, supported by the organical solidarity, is based on a social convention i.e. on the mutuallyconditioned and mutually-beneficial social-economical and spiritualcultural partnership of the regions, countries and social layers of the population. The social convention is regarded by us as a contract of a particular quality between the subjects that pursue a policy of peace, mutual respect, friendship, trust and cooperation. In a narrower sense this social action directed on to the mutually living aimed at resolving the existing controversies. Conventional relations appear as a result of repeating more or less stable conventional interactions. Conventional relationships between people, social groups, social institutions, 
authorities form together the social conventionality of the rural and urban communities, working communities, formal and non-formal entities, sides of a conflict.

The social convention is interpreted as the quality of the social subjects to coexist on the basis of all types of agreements. As indicators of the social-conventional sustainability development could be mentioned the values of the individuals, the ensuring of their rights and freedoms, the creation of conditions for the self-fulfillment of the personality, trust, civic engagement of the population, political activity, all taking together describe the essence of the social-conventional mechanism for the sustainable development of the society.

The comprehension of the core principles of the interrelationship between the conventionality and the sustainable development of the social systems would allow to better understand the issues of the consolidation of society, the strengthening of the social unity based on the launching of a national idea.

The most important condition for the consolidation of the sustainable development of the society is represented by the improvement of the democratic mechanism in order to strengthen the social interests, creating an enabling environment for the increasing of conventionality, and the overcoming of the disparities that block solidarity.

The changes in the economic and social spheres, including those linked to the issues of the sustainable regional development, require an institutional support, the insufficiency of which is one of the most striking causes for the hindering of the processes for sustainable development.

Thus, according to our opinion, the social-conventional mechanism of the sustainable development is based on a system conventionally behavioral practices in the interrelation of individuals, groups and social institutions. The sustainability of social development could be supported by an effective institutional platform, based on high-quality regional governance, balanced strategy for development, the awareness of the social responsibility of business agents, a partnership between society, business and authorities. While considering the subjective factors, the area of research is extended to the expectations and concerns of the people living there.

For example, the studies of the economic development revealed the aspects connected with the well-being of the population, which depend not only on the state of the economy, but also on the political stability and security, religious tolerance, the development on the civil society. The focus of the research is oriented on the socially conditioned factors, based on meaningful and vital value standards and the behavioral 
practices of the inhabitants of the considered region (Smirnova 2012: 290-302).

In the context of a conflict the mechanisms of the social convention allow to create a conventional platform for the resolving of the perspectives of the belligerent parties, taking into account the subjective component. The Moldovan-Transnistrian conflict did not receive yet a systemic conventional appreciation of sustainability, of the level of credibility between the sides or an effectiveness appreciation of the applied measures in order to form it on an expertise level.

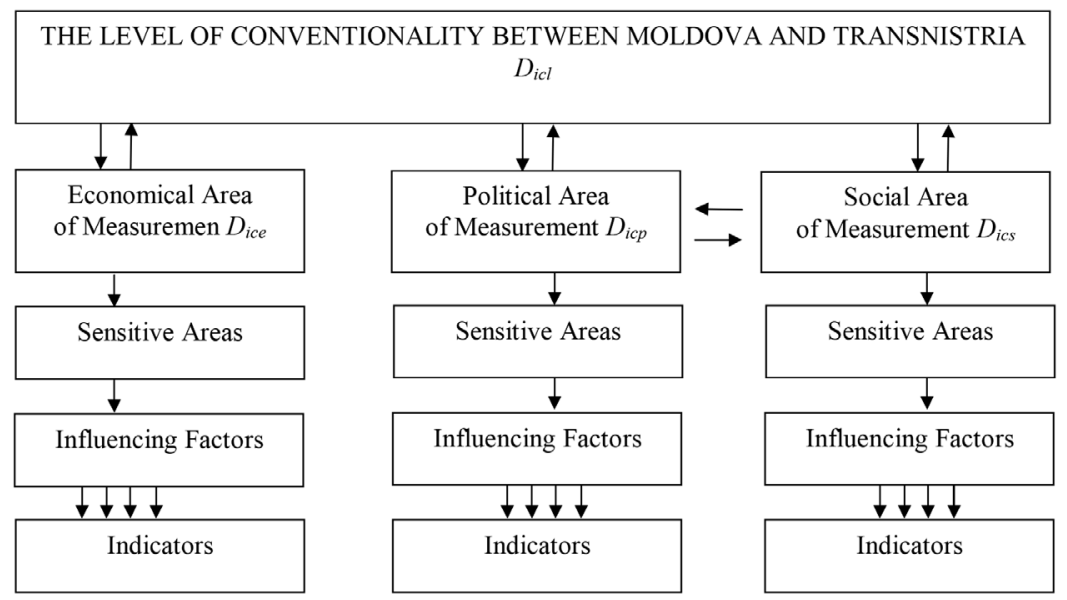

Fig. 1. The measurement chart of the conventionality between Moldova and Transnistria.

The contemporary social practice, regardless of the considerable number of conflicting border regions, lacks an effective methodology of measuring the conventionality. This circumstance makes it actual to develop a methodology of appreciation of the social conventionality between conflicting sides. The elaboration, executed and implimented on the instance of the Moldovan-Transnistrian conflict could serve as a route map to enhance the sustainability in other conflicting border zones.

The research of the mentioned issue is actualized by the following fact. Among the European policies elaborated on the territories of the post-Soviet countries the most significant for a period of time was that of the European Neighborhood Policy. It is continued today by the Program of the Eastern Partnership, including Moldova, Ukraine, Byelorussia, Georgia, Armenia and Azerbaijan. In 2014 when Moldova, Ukraine and Georgia signed the Association Agreement with the EU and the Free 
Trade Area Agreement with the EU, these countries faced serious barriers in the accomplishment of the European integrational intentions. The emergence of these difficulties are not only connected with the Russian countersanctions but also with the existing unresolved conflicts on the territory of these countries. The building of trust in the border conflicting regions became the main tool of the European Union in the promoting the current policy. A trustworthy appreciation of the effectiveness of this tool is an object of direct interest both of the conflicting countries, and of the guarantor countries and observer missions.

The methodology of measuring the conventionality which we propose include three areas of measurement: economic, political and social (fig. 1) The appreciation of the state of these areas could be carried out on the basis of the convention indexes of their composing factors.

During the first stage we determine on the analytical basis the most problematic and sensible areas of the interrelationship between the sides. On the next stage the factors which influence the formation of the conventionality are defined. For the analyzing of the conventionality in inter-ethnical relationships and for the building of the body of factors, influencing them and organization of joint expert commissions is advised. The participation of the key experts is required: political scientists, economists, experts regarding security protection, representatives of the civil society, former officials, sociologists and representatives of the community. Moreover, the key questions of the elaboration of the methodology of research, the formation of conclusions and recommendation were all discussed with the assistance of the international expertise in the matters of development, including the zones of frozen conflicts (Bobkova 2017: 141-143).

In order to illustrate the application of the elaborated model in practice we will provide some examples in from the studies of trade relationships in area of border regions. The following research ${ }^{1}$ demonstrated that "the communication between the sides of the conflict" was one of the most problematic factors, influencing the trust in trade between the both sides of the river. The problems in communications between the sides of a conflict according to the opinion of the experts has a value of 7,17 (out of 10 possible). But this factor is more important for the Moldovan experts, with a value of 7,64 it is on the third place in the rating of importance. According to the Transnistrian experts, the level of this factor is 6,50, but in the importance rating it is down on the lowest, the eighth place. The trust index of the factor "the communication between the sides of the conflict" is about 0,078 and attests a very high level of mistrust between the sides. Among the businessmen from Moldova this index rates 0,054, and among the Transnistrian businessmen it is equal to 0,103. 
The referential factor "The Interpersonal and Institutional Trust" was defined by the experts as to take the sixth rate according to the importance. In the opinion of the Transnistrian counter parts in the survey, the value of this factor is as a whole quite satisfactory - the factor index is 0,502. A rather higher index of criticality was demonstrated by the participating researchers from Moldova - the factor index is 0,314 . The average index of the above-mentioned factor is 0,454 , which corresponds to the "satisfactory level of trust, much above the lowest admitted value, and requiring actions in improving the situation, the relation develop with difficulties".

Considering the index of confidence in trade we should mention that all the indicators of this index were placed in the "very badly" column. Thus the state of things in the performing of mutual trade is in a critical phase and according to the authorial scale could be characterized as "distrust, the situation does not correspond to the expected purposes. Absolutely unacceptable level". All in all, for the further research in the elaboration of confidence measures and trade development between Moldova and Transnistria there were highlighted 14 mostly sensible indicators (Chart 1).

\section{Indicators recommended for the elaboration of confidence building measures and trade development between Moldova and Transnistria}

\begin{tabular}{|l|c|c|c|}
\hline \multirow{2}{*}{$\begin{array}{c}\text { The Basis Indicators, defined by the } \\
\text { experts }\end{array}$} & \multicolumn{2}{|c|}{ Index of conventionality } \\
\cline { 2 - 4 } & Moldova & Transnistria & Average \\
\hline $\begin{array}{l}\text { Absence of mechanism, providing } \\
\text { unrestricted movement of persons, good } \\
\text { sand cargoes both on the territories of } \\
\text { Moldova and Transnistria, and beyond their } \\
\text { borders }\end{array}$ & 0,012 & 0,046 & 0,036 \\
\hline $\begin{array}{l}\text { Absence of access for the Transnistrian } \\
\text { economic entities to the international } \\
\text { financing (credits and grants) }\end{array}$ & 0,048 & 0,036 & 0,039 \\
\hline $\begin{array}{l}\text { Absence of formalized agreements between } \\
\text { the banks of Moldova and Transnistria }\end{array}$ & 0,024 & 0,046 & 0,039 \\
\hline Absence of direct telephone communication & 0,012 & 0,064 & 0,048 \\
\hline Uncertain mode of mutual trade relations & 0,036 & 0,056 & 0,050 \\
\hline $\begin{array}{l}\text { Absence of non-recognition of direct } \\
\text { applicability of phyto-sanitary and } \\
\text { veterinary certificates of conformity and } \\
\text { shipping documents issued by authorized } \\
\text { structures of both sides }\end{array}$ & 0,012 & 0,107 & 0,079 \\
\hline $\begin{array}{l}\text { Absence of renewed agreements between } \\
\text { the customs services }\end{array}$ & 0,012 & 0,107 & 0,079 \\
\hline
\end{tabular}




\begin{tabular}{|l|c|c|c|}
\hline \multirow{2}{*}{$\begin{array}{c}\text { The Basis Indicators, defined by the } \\
\text { experts }\end{array}$} & \multicolumn{3}{|c|}{ Index of conventionality } \\
\cline { 2 - 4 } & Moldova & Transnistria & Average \\
\hline $\begin{array}{l}\text { Ambiguous standing of the Transnistrian } \\
\text { good for taxation purposes in Moldova }\end{array}$ & 0,012 & 0,112 & 0,082 \\
\hline $\begin{array}{l}\text { Absence of free shipment of cargoes } \\
\text { between the sides when there are customs } \\
\text { services and fiscal administration in both } \\
\text { regions }\end{array}$ & 0,012 & 0,148 & 0.107 \\
\hline $\begin{array}{l}\text { The multi-vectorial direction in the } \\
\text { harmonization of the standardization, } \\
\text { certification, metrology, control and } \\
\text { supervision systems in Moldova and }\end{array}$ & 0,012 & 0,184 & 0,129 \\
Transnistria & & & \\
\hline $\begin{array}{l}\text { Absence of formalized agreements between } \\
\text { the authorities of Moldova and Transnistria } \\
\text { in the field of norms and regulations about } \\
\text { mutual home trade and foreign trade for } \\
\text { Transnistrian enterprises }\end{array}$ & 0,119 & 0,225 & 0,193 \\
\hline $\begin{array}{l}\text { Differences in the fiscal system in Moldova } \\
\text { and Transnistria }\end{array}$ & 0,155 & 0,209 & 0,193 \\
\hline $\begin{array}{l}\text { Shared interest of Moldova and Transnistria } \\
\text { in the development of trade with the } \\
\text { countries of the European Union }\end{array}$ & 0,155 & 0,649 & 0.501 \\
\hline $\begin{array}{l}\text { Shared interest of Moldova and Transnistria } \\
\text { in the development of trade with the } \\
\text { countries of the Commonwealth of } \\
\text { Independent States and the Eurasian } \\
\text { European Union }\end{array}$ & 0,215 & 0,751 & 0,590 \\
\hline
\end{tabular}

In order to achieve the maximum effect for the formation of sustainable social development of both sides and considering the definition of the most sensitive indicators, the rewash elaborated an agreed position about the priority directions in the development of trade relationships (Bobkova 2016). The methodology and the obtained results demonstrate the possibility of controlling the sustainability of development in this sphere, of taking effective administrative decisions and to formulate propriety actions, which would allow the normalizing of trade between Moldova and Transnistria. The conclusion of the present research could be usefully applied in the building a step-bystep "Sustainability Route Plan".

\section{Note}

1.A great importance for the optimization of the process of the social conventionality and building of trust had the studies about the basic stereotypes which the inhabitants of the border region have about each 
other. The approval of the methodology was performed in the frame work of the project "The Social Interrelationship in the Changing Society: Building of Trust and Stability" implemented by the National Center of Analytical Research "New Age" with the financial support from UNDP in 2012-2013. In 2015 the Non-Commercial Partnership "Sigma-expert" with the support of Conflict, Stability and Security Fund (CSSF) and the British Embassy in Moldova had implemented the project "Index of Confidence in Trade between Moldova and Transnistria". These studies do need a strict keeping of the methodology rigor and periodicity, as the data about confidence, having a fragmentary character would distort the understanding of the issues in the relationships of the belligerent parties.

\section{REFERENCES}

Aytimov, A.S., Aksenov, V.A., Alekseev, Yu.V. et al. (2016) "TRIIS" - proekt: "Territorial'naya (regional'naya) innovatsionno-investitsionnaya sistema" kak novaya tekhnologicheskaya platforma sotsial'no-ekonomicheskogo razvitiya regionov Rossii: Posobie po antikrizisnomu upravleniyu ekonomikoy i obshchestvom [TRIIS - "Territorial (regional) innovation investment system" as a new technological platform for social and economic development of the regions of Russia: A manual on crisis management of the economy and society]. Moscow: Sputnik +.

Bobkova, E. (2017) Trust in trade between parties of the conflict as a condition of sus-tainable development of the region: measurement methodology. Mezhdunarodnyy nauchno-issledovatel'skiy zhurnal. 1-3(55). pp. 141-143.

Bobkova, E. (2016) Index of confidence in trade between Moldova and Transnistria. Chișinău: Tiraspol.

Zang,V.B. (1999) Sinergeticheskaya ekonomika. Vremya i peremeny v nelineynoy eko-nomicheskoy teorii [Synergetic economy. Time and changes in nonlinear economic theory]. Mosocw: Mir.

Leksin, V.N. \& Shvetsov, A.N. (2012) Reformy i regiony: Sistemnyy analiz protsessov reformirovaniya regional'noy ekonomiki, stanovleniya federalizma $i$ mestnogo samoupravleniya [Reforms and regions: System analysis of the processes of reforming the regional economy, the formation of federalism and local self-government]. Moscow: LENAND.

Lektorskiy,V.A. (2010) Sub"ekt v istorii filosofii: problemy i dostizheniya [Subject in the history of philosophy: problems and achievements]. Metodologiya $i$ istoriya psikhologii. 5(1). pp. 5-18.

Smirnova, R.A. (2012) Sel'skie regiony kak ob"ekt sotsiologicheskogo issledovaniya [Rural regions as an object of sociological research]. Sotsiologicheskiy al'manakh. 3. pp. 290-302.

Stepin, V.S. (2003) Samorazvivayushchiesya sistemy i postneklassicheskaya 
ratsional'nost' [Self-developing systems and post-non-classical rationality]. Voprosy filosofii. 8. pp. 5-17.

\section{ЛИТЕРАТУРА}

Айтимов и др. 2016 - Айтимов А.С., Аксенов В.А., Алексеев Ю.В. и др. «ТРИИС» - проект: «Территориальная (региональная) инновационно-инвестиционная система» как новая технологическая платформа социальноэкономического развития регионов России: Пособие по антикризисному управлению экономикой и обществом / под общ. ред. А.Ф. Простова. М.: Спутник +, 2016.135 с.

Bobkova 2017 - Bobkova E. Trust in trade between parties of the conflict as a condition of sustainable development of the region: measurement methodology // Международный научно-исследовательский журнал. 2017. № 1-3 (55). C. 141-143.

Bobkova 2016 - Bobkova E. Index of confidence in trade between Moldova and Transnistria. Chisinau: Tiraspol, 2016. 56 p.

Занг 1999 - Занг В.Б. Синергетическая экономика. Время и перемены В нелинейной экономической теории. М.: Мир, 1999. 335 с.

Лексин 2012 - Лексин В.Н., Швецов А.Н. Реформы и регионы: Системный анализ процессов реформирования региональной экономики, становления федерализма и местного самоуправления. М.: ЛЕНАНД, 2012. 1024 с.

Лекторский 2010 - Лекторский В.А. Субъект в истории философии: проблемы и достижения // Методология и история психологии. 2010. Т. 5, вып. 1. С. 5-18.

Смирнова 2012 - Смирнова Р.А. Сельские регионы как объект социологического исследования // Социологический альманах / Институт социологии НАН Беларуси (Минск). 2012. № 3. С. 290-302.

Степин 2003 - Степин B.C. Саморазвивающиеся системы и постнеклассическая рациональность // Вопросы философии. 2003. № 8. С. 5-17.

Бобкова Елена Михайловна - кандидат социологических наук, доцент, декан факультета общественных наук Приднестровского государственного университета им. Т.Г.Шевченко (Республика Молдова, Приднестровье).

Elena Bobkova - Taras Shevchenko State University of Transnistria (Moldova, Transnistria).

E-mail: icnew-age@yandex.ru 